\title{
Distribution of S100-Positive Cells in Islets of Langerhans of the Fetal and Adult Human Pancreas
}

\author{
DOI: 10.17691/stm2015.7.3.08
}

Received May 26, 2014

A.E. Proschina, PhD, Associate Professor, Senior Researcher, Laboratory of Nervous System Development;

Y.S. Krivova, PhD, Senior Researcher, Laboratory of Nervous System Development;

V.M. Barabanov, PhD, Leading Researcher, Laboratory of Nervous System Development;

S.V. Saveliev, DSc, Professor, Head of Laboratory of Nervous System Development

Research Institute of Human Morphology, Zurupy St., 3, Moscow, Russian Federation, 117418

The aim of the investigation was to study the distribution of S100-positive cells in the islets of Langerhans of human pancreas during prenatal and early postnatal development, as well as in adult humans.

Materials and Methods. Using antibodies to S100 protein, to main hormones produced in the islets of Langerhans in human pancreas (insulin, glucagon and somatostatin), and to neuron-specific enolase (NSE) we carried out an immunohistochemical analysis of human pancreatic samples. The samples were taken from adults without pancreatic diseases, from patients with type 2 diabetes mellitus, as well as from fetuses and newborns.

Results. Two types of S100-positive cells can be found in human islets of Langerhans starting from gestation week 15-16: cells located on islet periphery, and cells situated inside an islet. Cells located on periphery are flattened and have small amount of cytoplasm. These cells have long processes extending mainly along periphery. The cells located inside islets are oval- or round-shaped, and generally have no processes.

Conclusion. In an early fetal period in islets of Langerhans of human pancreas, two types of S100-positive cells appear, they being different in their structure. The cells on periphery are similar morphologically to glial cells. The cells inside islets are no different in their structure from other endocrine cells. Two types of S100-positive cells can be suggested to be of importance both in islet morphology, and in the regulation of hormones expressed by endocrine cells.

Key words: islets of Langerhans; S100 protein; insulin; glucagon; somatostatin; NSE; neuro-insular complexes; human development.

Diabetes mellitus is one of the most common diseases worldwide. Despite the advances in the disease treatment, the number of patients and complications keep increasing [1]. Moreover, most patients have type 2 diabetes mellitus, which can remain undetectable for a long period of time. Currently, new methods of diabetes mellitus treatment are being under development, they aim at achieving the compensation of carbohydrate and lipid metabolism that can be attained only by technologies with carbohydrate metabolic control feedback. An ideal fulfillment of such state is to develop structures functioning according to hormonal control of carbohydrate metabolism [2]. However, to achieve the aim we need detailed information on structure and functions of endocrine cells of human pancreas.

Currently, progress of diabetes mellitus of both types is associated with dysfunction or selective death of $\beta$ - cells of Langerhans islets of pancreas, which synthesize insulin [3]. In addition to these cells, the endocrine part of pancreas has been describe to have some other types of cells, the main of them are $\alpha$-cells synthesizing glucagon, $\delta$-cells synthesizing somatostatin, PP-cells synthesizing pancreatic polypeptide, and $\varepsilon$-cells synthesizing ghrelin. Pancreas of some mammals have been found to have some other cell types, e.g., EC-cells, which synthesize serotonin and G-cells synthesizing gastrin. However, they are few and can be found at some stages of prenatal development $[4,5]$.

Except the mentioned cell types, as early as in 1989 human pancreas was discovered to have S100containing cells [6]. They were found in all islets, and according to the author, formed a separate cell population. The cells positive to $\mathrm{S} 100$ protein were immunonegative to antibodies to insulin, glucagon

For contacts: Proschina Alexandra Evgenievna, e-mail: proschina@mtu-net.ru 
and pancreatic polypeptide. Generally, S100-positive (S100+cells) and $\delta$-cells represented two different populations, though sometimes it was possible to reveal colocalization of $\mathrm{S} 100$ and somatostatin.

A variety of animals were discovered to have S100+cells [7-10]. Data on their localization, form, as well as their colocalization with hormones of the endocrine part of pancreas are considerably contradictory. For instance, in rats $\mathbf{S 1 0 0 + c e l l s ~ w e r e ~ f o u n d ~ o n ~ t h e ~ p e r i p h e r y ~}$ of islets, and believed to form something similar to a glial sheath. Guinea pigs and cynomolgus monkeys (Macaca irus) were found to have two different types of $S 100+$ cells: one type cells locating on islet periphery have processes and can be considered as glial cells; the second type cells are revealed inside islets, morphologically they being similar to endocrine cells. Moreover, in guinea pigs $\mathbf{S 1 0 0 + c e l l s ~ o f ~ t h e ~ s e c o n d ~ t y p e ~ c o e x p r e s s ~ i n s u l i n , ~}$ while in cynomolgus monkeys they form a separate population. In addition, in some animal species [11] and in human [12] S100+cells are found as a part of neuroinsular complexes.

The aim of the investigation was to study the distribution of S100-positive cells in the islets of Langerhans of human pancreas during prenatal and early postnatal development, as well as in adult humans.

Materials and Methods. The study was carried out on autopsy material of human pancreas (fetuses, newborns, adults) from the collection of the laboratory of nervous system development, Research Institute of Human Morphology, as well as those collected in 20072012 in Moscow hospitals. Totally, we used pancreatic samples of 27 human fetuses at different developmental stages (fetal age being 10-35 gestational weeks), 4 premature newborns aged from several hours to 13 days, 2 full-term newborns, 1 child (aged 3 months 17 days), 15 adults (aged from 30 to 90 ) with neither pancreatic diseases nor carbohydrate metabolic imbalance, and 10 adults (aged 42-82) suffering from type 2 diabetes mellitus. The survey was approved by a local Ethics Committee.

The material was fixed in $10 \%$ acid formaline, neutral formaline $(4 \%$ paraformaldehyde on $0.1 \mathrm{M}$ phosphate buffer, $\mathrm{pH}=7.5$ ), or in Bouin's fluid followed by dehydration in high-proof alcohol and dioxane, and then the material was embedded in histomix (BioVitrum, Russia). We made serial sections, $10 \mu \mathrm{m}$ thick, and for some samples the sections, 5 and $3 \mu \mathrm{m}$ thick, were made as well. During immunohistochemical reactions, deparaffined hydrated sections were treated with $3 \% \mathrm{H}_{2} \mathrm{O}_{2}$ solution for 10 min to block endogenous peroxidase. For the purpose of nonspecific binding blockage, the sections were treated with Ultra V Block (Lab Vision Corp., USA) for 5 min and rinsed in PBS, $\mathrm{pH}=7.3-7.5$. The Table represents the antibodies used in the study, and immunohistochemical conditions.

Next, we used UltraVision Detection System Antipolyvalent, HRP/DAB (Lab Vision Corp., USA) according to the specification of a manufacturer. The final stage included the treatment of sections with a fresh chromogen solution (DAB, Lab Vision Corp., USA).

To study the distribution of basic hormones and panneuronal markers in human pancreas in more detail we carried out double immunohistochemical staining reactions. The sequential sections of all pancreatic samples underwent the reactions to reveal the following antigens:

a) NSE (mouse monoclonal antibodies) + glucagon (rabbit polyclonal antibodies);

b) NSE (mouse monoclonal antibodies) + insulin (rabbit polyclonal antibodies);

c) insulin (murine monoclonal antibodies) + somatostatin (rabbit polyclonal antibodies);

d) insulin (mouse monoclonal antibodies) + $\mathbf{S 1 0 0}$ (rabbit polyclonal antibodies);

e) NSE (mouse monoclonal antibodies) + $\mathbf{S 1 0 0}$ (rabbit polyclonal antibodies).

For this purpose we used MultiVision Polymer Detection System: MultiVision anti-rabbit/HRP + antimouse/AP polymers (Thermo Fisher Scientific Inc., USA).

All the preparations obtained were visually assessed using microscopes Leica DMLS (Leica, Germany) and Mikmed-6 (Lomo, Russia). Video capture was performed using the cameras Sony SSc-Dc50P (Sony, Japan) and Lomo TCA-5.0C (Lomo, Russia), respectively.

Results. Starting from a prefetal period, we revealed the immunopositive reaction to $\mathbf{S} 100$ protein in human pancreas in the elements of nervous system (ganglia,

Antibodies used in the study

\begin{tabular}{llccl}
\hline \multicolumn{1}{c}{ Antigens } & Origin & Dilution & Incubation & \multicolumn{1}{c}{ Manufacturer } \\
\hline Insulin & Murine & $1: 400$ & $30 \mathrm{~min}, 25^{\circ} \mathrm{C}$ & Thermo Fisher Scientific, Inc., USA \\
\hline Insulin & Rabbit & $1: 400$ & $30 \mathrm{~min}, 25^{\circ} \mathrm{C}$ & Santa Cruz Biotechnology, Inc., Germany \\
\hline Glucagon & Rabbit & $1: 100$ & $30 \mathrm{~min}, 25^{\circ} \mathrm{C}$ & Thermo Fisher Scientific, Inc., USA \\
\hline Somatostatin & Rabbit & $1: 100$ & $30 \mathrm{~min}, 25^{\circ} \mathrm{C}$ & Thermo Fisher Scientific, Inc., USA \\
\hline NSE & Murine & $1: 200$ & $30 \mathrm{~min}, 25^{\circ} \mathrm{C}$ & Thermo Fisher Scientific, Inc., USA \\
\hline S100 protein & Rabbit & $1: 100$ & $30 \mathrm{~min}, 25^{\circ} \mathrm{C}$ & Thermo Fisher Scientific, Inc., USA \\
\hline
\end{tabular}



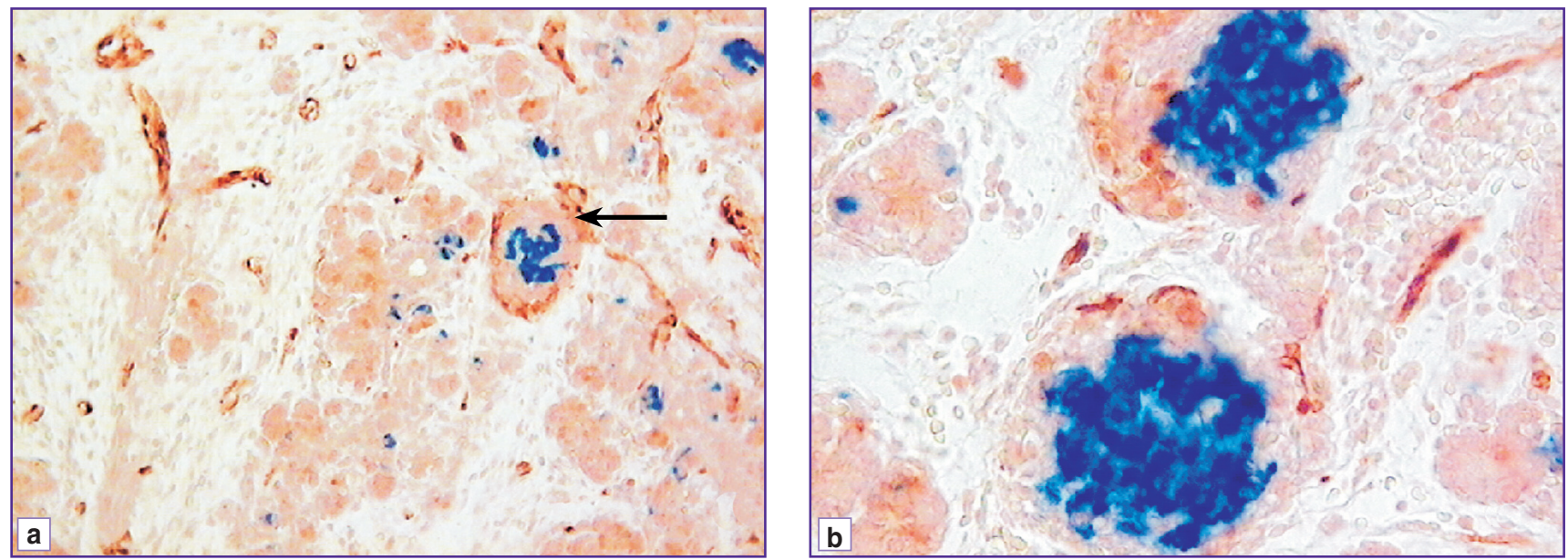

Figure 1. Double immunohistochemical reaction to $S 100$ protein (red) and insulin (blue) in human pancreas in a prenatal period: (a) S100+cells in nerves, ganglia, on periphery of islets, and as a part of neuro-insular complex (arrow), 16-week fetus, $\times 20$; (b) islets of Langerhans of mantle type (cells containing insulin are centrally located, while S100+cells of both types - on periphery), 1516-week fetus, $\times 40$
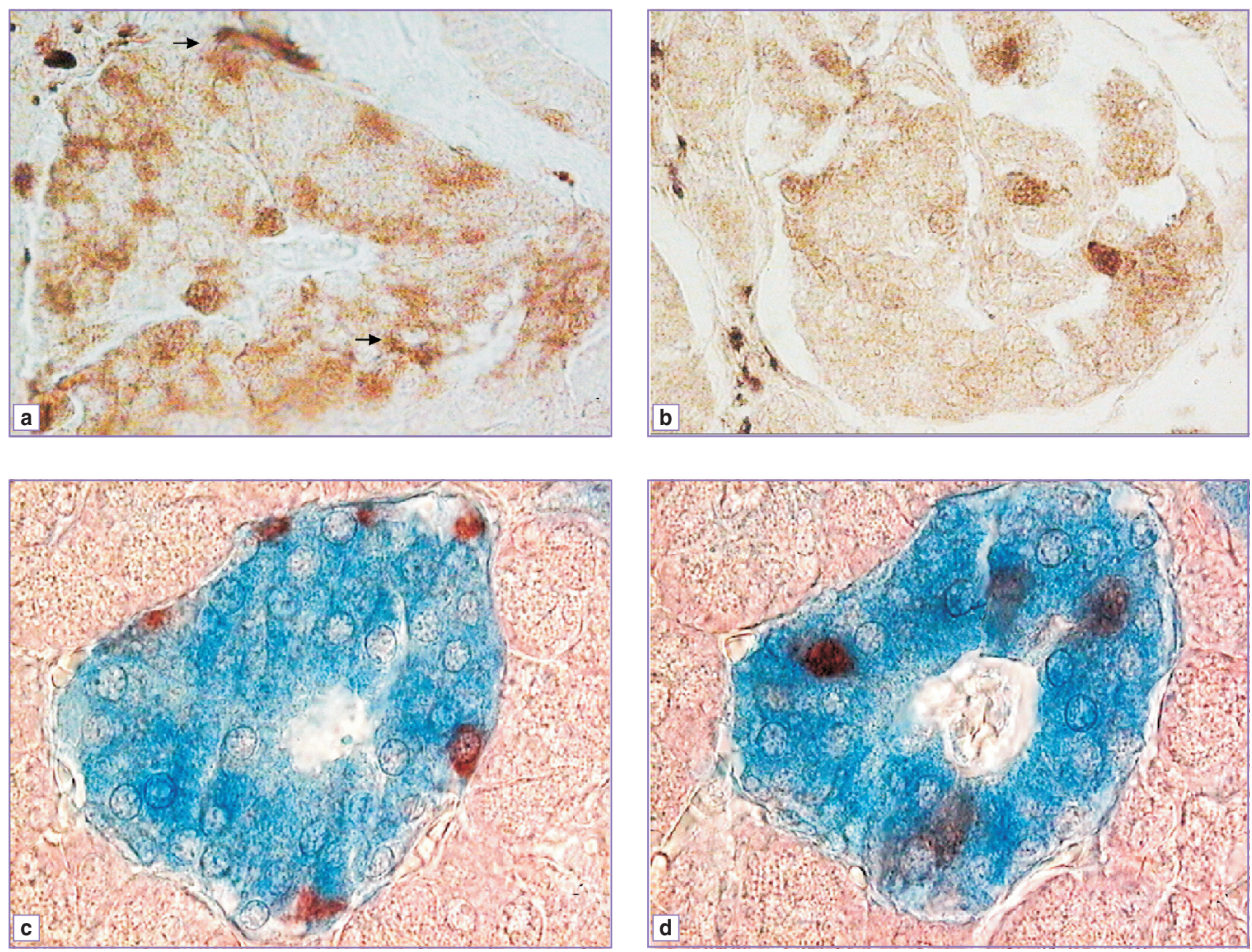

Figure 2. Immunohistochemical reaction to $S 100$ protein in islets of Langerhans in adults: (a) 80-year-old man, arrows indicate S100+cells with processes on the islet periphery; $\times 100$; (b) 76-year-old man with type 2 diabetes mellitus, $\times 100$; (c), (d) 77-year-old man, double reaction on sequential sections; $\times 40$ : (c) NSE (blue) + glucagon (red), (d) NSE (blue) + S100 (red) 
nerves). Moreover, beginning from a gestation week 14 , S100+cells can be found on periphery of some islets of pancreas as well. A positive reaction to the protein was revealed both in a nucleus, and a cytoplasm of these cells. S100+cells have long processes, which also extend along the islet periphery though forming no completely close sheath. Such islets are frequently seen to form a neuro-insular complex with ganglia of the autonomic nervous system (Figure 1 (a)).

As early as during $15-16$ gestation weeks, $S 100+$ cells appear in a number of islets not only on periphery, but also inside the islets. Such cells are primarily ovalshaped, with no long processes, they being larger in size than those located on periphery. S100+cells are revealed primarily in islets whose diameter being not less $40 \mu \mathrm{m}$, frequently located near large ducts. Double immunohistochemical staining in serial sections showed S100+cells during prenatal development to be located mainly in the area of glucagon and somatostatin localization (Figure 1 (b)).

It should be noted that the value of antibody reaction to $\mathbf{S 1 0 0}$ protein varies significantly in different structures of nervous system and the endocrine part of pancreas: it is most intense in the elements of nervous system (large nerves and ganglia); in the cells located on islet periphery it is more intense than in those situated inside the islets.

We also found both types of S100+cells in islets in a prenatal, early postnatal developmental period and in adults (Figure $2(a),(b)$ ).

During the present study we did not carry out a morphometrical analysis, since the number of the cells revealed depends heavily on material integrity and fixation quality, though immunohistochemical findings suggest that with the increase of islet size, the number of cells found inside an islet grows. In addition, the number of such cells is significantly less than insulinor glucagon-containing cells, and comparable to the number of somatostatin-containing cells. However, their arrangement in islets of adults differs from that of glucagon- and somatostatin-containing cells: $\alpha$ - and $\delta$ cells are usually located on islet periphery or (in large islets) along blood capillaries, while $\mathbf{S 1 0 0 + c e l l s ~ a r e ~}$ found in the area of insulin-containing cells (Figure 2 (c), (d)). Moreover, S100+cells can be both insulin-positive, and insulin-negative.

Cells located inside the islets were always found to have colocalization of S100 and NSE. The situation appeared to be similar in pancreatic samples of patients suffering from type 2 diabetes mellitus.

Discussion. $\mathrm{S} 100$ protein, a calcium binding protein first described by Moore in 1965, was long considered to be specific to nervous tissue. Currently, it has been found that there is a group of proteins (24 are known by now), which are divided functionally into three main subgroups: 1) proteins, which have only intracellular regulatory effects; 2) proteins, which function mainly as an extracellular signal; 3) proteins exercising both functions [13]. Inside cells, S100 proteins participate in the regulation of proliferation, differentiation and apoptosis, $\mathrm{Ca}^{2+}$-homeostasis and cell metabolism through the interaction with various protein-targets including enzymes and transcription factor receptors. Extracellularly, S100 proteins produce a regulatory effect on a great deal of various cell types (neurons, astrocytes, Schwann cells, microglia, mast cells, articular chondrocytes, endothelial and vascular smooth muscle cells, myoblast and cardiomyocyte epithelial cells, monocytes, macrophages, neutrophils, lymphocytes), and by that participating in the formation of an innate and acquired immune response, and regulating cell migration and chemotaxis, tissue development and regeneration, as well as inflammatory processes and tissue growth $[13,14]$.

Islets of Langerhans in human pancreas were found to have two types of $\mathbf{S 1 0 0 + c e l l s ~ d u r i n g ~ a l l ~ t h e ~ p e r i o d s ~}$ under study starting from an early fetal period: the cells located along islet periphery, and the cells located inside islets. These cell types differ.

Morphologically, the cells located on periphery resemble those found earlier in rodent pancreatic islets $[8,9,15]$. Currently, most researchers consider them to be glial. However, their functional role is unclear. Moreover, some studies [8, 10, 12] have shown the relationship of S100+cells with neuro-insular complexes. Neuro-endocrine complexes are most numerous in fetuses during midpregnancy and an early third trimester of pregnancy, when human pancreas is known to have active morphogenesis of islets [12]. Therefore, we suppose $\mathrm{S} 100+$ cells to have an ancillary character in the formation of inner architecture of mature islets.

Morphologically, the cells located inside islets are not different from other endocrine cells and similar to those found earlier in adult humans including patients with diabetes mellitus and pancreatitis [6], as well as in different animal species $[7,8,10]$.

Some authors including those studying human S100+cells [6] believe them to be a particular cell type, while other researchers $[7,8]$ have found colocalization of S100 with insulin.

The analysis of serial sections in our study demonstrated the differences in the number and arrangement of $S 100+$ cells, $\alpha$ - and $\delta$-cells in adults. It should be noted that size and form of islets have an effect on relative position of these cells inside the islets [16]. Adult pancreas was found to have various forms of endocrine part arrangement: single cells containing hormones, their small clusters, mantle (murine) type islets and mosaic islets. Insulin-containing cells in mantle islets are centrally located, and glucagon-containing cells are on the periphery, while in mosaic cells glucagoncontaining cells are both on the periphery, and along capillaries dividing an islet into separate clusters. In a fetal period the pancreas was found to have the so called bipolar islet type, in which the cells containing insulin 
and glucagon form two "poles" of an islet [17]. In adult humans such islets were not revealed. During prenatal development, different distribution types of endocrine cells appear as the pancreas develops [18-20].

In fetuses of different ages we found $\mathrm{S100+ \text {cells }}$ in mantle and bipolar islets primarily in the area of glucagon- and somatostatin-containing cells. Human mature mosaic islets appeared to have much less S100+cells than glucagon-containing cells. Their number was comparable to that of somatostatin-containing cells. However, S100-containing cells are located in these islets not on periphery but along capillaries (unlike $\alpha$ - and $\delta$-cells), and together with $\beta$-cells. In addition, S100+cells are less than those containing insulin, and only a few islet cells were found to have S100 and insulin colocalization. By means of double staining we succeeded to reveal clear colocalization of S100+cells and NSE. In addition, total number of $S 100+$ cells was much less than NSE. Thus, S100 protein presence or absence in cells can be related to different functional status of hormoneproducing cells. However, physiological experiments are required to confirm the hypothesis.

Islets of Langerhans are secretion functional units, where the activity between $\beta$-cells coordinates simultaneous insulin release. Secretory response of a whole islet is more than the sum of responses of single $\beta$-cells. Recent studies have shown the expression of extracellular calcium-sensing receptor (CaSR) of $\beta$-cells in rodents and in human [21]. The receptor reveals slight local changes of free calcium occurring immediately after nutrients injected and/or non-food stimulation. The findings confirm the possibility that CaSR provides an alternative mechanism of autocrine and paracrine regulation between $\beta$-cells. Some of $S 100$ proteins just regulate cell functions due to activation of surface receptors.

Therefore, taking into consideration the functions of calcium binding protein S100 in CNS [13, 14], we can assume $\mathbf{S 1 0 0 + c e l l s}$ of type 2 located inside islets are also relevant in synchronization of expressing endocrine hormones, since it is a calcium-dependent process [21].

Conclusion. Human pancreas appeared to have two types of S100-positive cells. These cells were found in humans of different age starting from an early fetal period. We assume type 1 cells located on islet periphery to be glial and necessary to form cell architecture of islets. Type 2 cells located inside the islets are likely to act as pacemakers controlling matched release of hormones by endocrine cells. Further studies of the function of these cells in the endocrine part of pancreas are needed to determine the possibility to use the data obtained in diabetes mellitus therapy.

Study Funding. The study was sponsored by a specialized endowment fund ("Fundamental") to support biological and medical studies, and partially supported by Russian Foundation for Basic Research grant No.1504-03155.
Conflicts of Interest. The authors have no conflicts of interest to declare.

\section{References}

1. IDF Diabetes Atlas. 6-th ed. Brussels: International Diabetes Federation; 2013; 159 p.

2. Dedov I.I., Balabolkin M.I., Klebanova E.M. Modern aspects of pancreatic islet transplantation in diabetes mellitus. Diabetes mellitus 2004; 2: 34-41.

3. Scheen A.J. Diabetes mellitus in the elderly: insulin resistance and/or impaired insulin secretion? Diabetes \& Metabolism 2005; 31(1): 5S27-5S34, http://dx.doi.org/10.1016/ s1262-3636(05)73649-1.

4. Wierup N., Svensson H., Mulder H., Sundler F. The ghrelin cell: a novel developmentally regulated islet cell in the human pancreas. Regul Pept 2002; 107(1-3): 63-69, http:// dx.doi.org/10.1016/S0167-0115(02)00067-8.

5. Wierup N., Sundler F., Heller R.S. The islet ghrelin cell. J Mol Endocrinol 2013; 52(1): R35-R49, http://dx.doi. org/10.1530/jme-13-0122.

6. Lászik Z., Krenács T., Dobó E. S-100 protein immunoreactivity in human islets of Langerhans. Acta Morphol Hung 1989; 37(1-2): 117-124.

7. Takayanagi M., Watanabe T. Immunocytochemical colocalizations of insulin, aromatic L-amino acid decarboxylase, dopamine beta-hydroxylase, S-100 protein and chromogranin $\mathrm{A}$ in B-cells of the chicken endocrine pancreas. Tissue Cell 1996; 28(1): 17-24, http://dx.doi.org/10.1016/S00408166(96)80040-1.

8. Uchida T., Endo T. Identification of cell types containing S-100b protein-like immunoreactivity in the islets of Langerhans of the guinea pig pancreas with light and electron microscopy. Cell Tissue Res 1989; 255(2): 379-384, http://dx.doi. org/10.1007/bf00224121.

9. Sunami E., Kanazawa H., Hashizume H., Takeda M., Hatakeyama K., Ushiki T. Morphological characteristics of Schwann cells in the islets of Langerhans of the murine pancreas. Arch Histol Cytol 2001; 64(2): 191-201, http://doi. org/10.1679/aohc.64.191.

10. Girod C., Durand N., Raccurt M. Immunostaining of a cell type in the islets of Langerhans of the monkey Macaca irus by antibodies against S-100 protein. Cell Tissue Res 1987; 247(1): 11-16, http://dx.doi.org/10.1007/bf00216541.

11. Fujita $T$. Histological studies on the neuro-insular complex in the pancreas of some mammals. Z Zellforsch Mikrosk Anat 1959; 50: 94-109, http://dx.doi.org/10.1007/bf00342656.

12. Proshchina A.E., Krivova Y.S., Barabanov V.M., Saveliev S.V. Ontogeny of neuro-insular complexes and islets innervation in the human pancreas. Front Endocrinol 2014; 5: 57, http://dx.doi.org/10.3389/fendo.2014.00057.

13. Donato R., Cannon B.R., Sorci G., Riuzzi F., Hsu K., Weber D.Y., Geczy C.L. Functions of S100 proteins. Curr Mol Med 2013; 13(1): 24-57, http://dx.doi.org/10.2174/1566524011 307010024.

14. Donato R., Sorci G., Riuzzi F., Arcuri C., Bianchi R., Brozzi F., Tubaro C., Giambanco I. S100B's double life: intracellular regulator and extracellular signal. Biochim Biophys Acta 2009; 1793(6): 1008-1022, http://dx.doi.org/10.1016/ j.bbamcr.2008.11.009.

15. Fujita T., Iwanaga T., Nakajima T. Immunohistochemical detection of nervous system-specific proteins in normal and 
neoplastic paraneurons in the gut and pancreas. In: Gut peptides and ulcer. Miyoshi A. (editor). Tokyo: Biomedical Research Foundation; 1983; p. 81-88.

16. Proshchina A.E., Savel'yev S.V. Immunohistochemical study of $\alpha$ - and $\beta$-cell distribution in human pancreatic Langerhans islets of various types. Bull Exp Biol Med 2013; 155(6): 798-801, http://dx.doi.org/10.1007/s10517-013-2255-5.

17. Jeon J., Correa-Medina M., Ricordi C., Edlund H., Diez J.A. Endocrine cell clustering during human pancreas development. J Histochem Cytochem 2009; 57(9): 811-824, http://dx.doi.org/10.1369/jhc.2009.953307.

18. De Krijger R.R., Aanstoot H.J., Kranenburg G., Reinhard M., Visser W.J., Bruining G.J. The midgestational human fetal pancreas contains cells coexpressing islet hormones. Dev Biol 1992; 153(2): 368-375, http://dx.doi. org/10.1016/0012-1606(92)90121-V.

19. Piper K., Brickwood S., Turnpenny L.W., Cameron I.T., Ball S.G., Wilson D.I., Hanley N.A. Beta cell differentiation during early human pancreas development. $J$ Endocrinol 2004; 181(1): 11-23, http://dx.doi.org/10.1677/joe.0.1810011.

20. Meier J.J., Köhler C.U., Alkhatib B., Sergi C., Junker T., Klein H.H., Schmidt W.E., Fritsch H. Beta-cell development and turnover during prenatal life in humans. Eur J Endocrinol 2010; 162(3): 559-568, http://dx.doi.org/10.1530/EJE-09-1053.

21. Squires P.E., Jones P.M., Younis M.Y., Hills C.E. The calcium-sensing receptor and $\beta$-cell function. Vitam Horm 2014; 95: 249-267, http://dx.doi.org/10.1016/B978-0-12-800174-5. 00010-7. 